Nurbaiti. et al. Taman Bacaan Inovatif Dalam Upaya Peningkatan...

\title{
TAMAN BACAAN INOVATIF DALAM UPAYA PENINGKATAN KOGNITIF, AFEKTIF, DAN PSIKOMOTOR ANAK DI \\ TK DIVA ISLAMIC SCHOOL DAN TK DARUL MADANI
}

\author{
Nurbaiti ${ }^{1}$, Fatwa Imelda ${ }^{2}$ \\ ${ }^{12}$ Fakultas Keperawatan, Universitas Sumatera Utara \\ Email : etyakis@yahoo.com
}

\begin{abstract}
Abstrak
Taman bacaan inovatif ditujukan kepada anak usia dini (Preschool) dan orang tua murid adalah adalah sarana yang memfasilitasi untuk membaaca, melukis, menggambar, bermain puzzle dan wadah/tempat orang tua membaca berbagai buku tentang kesehatan, parenting, agama, tata boga, tata busana, dan cara bercocok tanam untu pengembangan ilmu pengetahuan dan kreatifitas ibu dan anak serta tempat untuk pelatihan screening cara penilaiana tumbuh kembang anak yang optimal. Kegiatan ini dapat memberi rangsangan atau stimulasi tumbuh kembang anak yang sesuai dengan tahap tumbuh kembang anak usia dini. Seluruh aktivitasnya dilakukan melalui pendekatan bermain sambil belajar.Keberhasilan pendidikan informal anak tidak bisa lepas dari dukungan peran serta orang tua sehingga diperlukan kerjasama dengan orang tua .Untuk itu orang tua berkewajiban memberikan stimulasi yang tepat agar anak bisa mencapai tumbuh kembang yang optimal yang mampu membentuk anak yang cerdas dan sehat. Kegiatan ini dilakukan sesuai rencana. Kegiatan yang dilakukan berupa Pelatihan screening gangguan tumbuh kembang anak pada guru dan orang tua,dan untuk anak-anak TK tersebut dilakukandeteksi tumbuh kembang anakdan stimulasi tumbuh kembang anak dengan mengajarkan cara membuat kreatifitas dari origami, mengajarkan mewarnai dan menyusun puzle, kemudian dilanjutkan dengan penyuluhan tentang hipertensi dan diabetes melitus. Dan penyediaan buku-buku buku tata boga, buku tata busana, cara bercocok tanam, dan cara membuat kerajinan tangan dari bahan sisa maupun dari bahan acrylic dll. Dan Buku untuk anak anak yang disediakan adalah buku : buku bergambar seperti buku dongeng, buku lancar membaca, buku aksara arab, buku agama seperti buku cerita nabi dan buku sejarah, buku berhitung
\end{abstract}

\section{Kata Kunci: Taman inovatif, Deteksi dini tumbuh kembang anak stimulasi tumbuh kembang anak.}

\section{PENDAHULUAN}

Golden age atau anak usia dini merupakan waktu paling cepat untuk memberikan bekal yang kuat kepada anak(Mcleod, 2009). Dimasa peka, kecepatan pertumbuhan otak anak sangat tinggi hingga mencapai 50 persen dari keseluruhan perkembangan otak anak selama hidupnya(Suryadi, A., 2007). Golden age merupakan masa yang sangat tepat untuk menggali segala potensi kecerdasan anak sebanyak-banyaknya kebutuhan bagi perkembangan anak usia TK (Aisyah, 2008).Salah satu program pendidikan yang tepat untuk meningkatkan minat membaca pada anak dari sejak usia dini adalah dengan mendirikan taman bacaan inovatif.

Sesuai dengan slogan buku adalah jendela dunia, karena dengan membaca buku 
Nurbaiti. et al. Taman Bacaan Inovatif Dalam Upaya Peningkatan...

seseorang akan memiliki ilmu dan pengetahuan yang luas, kemudian dapat membedakan mana yang baik dan mana yang buruk sehingga akan terbentuk pribadi yang jauh lebih baik dari sebelumnya.Namun ditengah upaya peningkatan mutu pendidikan, realitas social yang berkembang di masyarakat berjalan tidak sebanding dengan yang diharapkan. Anak-anak terpapar oleh media informasi game online yang menjamur dengan merubah kebiasaan anak yang seharusnya diberikan informasi melalui pengenalan kebiasaan membaca yang menyenangkan menjadi pola anak yang malas membaca dan menjadi terbiasa bermain game saja (Briawan D, Herawati T. (2008). Akibatnya, masa keemasan ini sering lepas dari amatan orangtua yang mengakibatkan karakter anak yang hedonis, asosial dan malpraktek. Hal ini dibuktikan dengan banyaknya anak remaja yang lari pada dunia narkoba, dan keputusan bunuh diri di usia dini. Para orang tua murid yang menunggu anaknya disekolah banyak menghabiskan waktunya dengan begitu saja tanpa diisi dengan ilmu yang bermanfaat yang dapat meningkatkan pengetahuan baik pengetahuan umum, agama maupun pengetahuan yang dapat meningkatkan ekonomi keluarga.

Berdasarkan studi diatas dari hasil diskusi dengan mitra didorong oleh kebutuhan anak-anak untuk menyalurkan hasrat membacanya maka diperlukan sebuah tempat untuk taman bacaan yang tidak hanya memberikan fasilitas buku-buku bacaan saja, tetapi diperlukan tempat sebagai taman bacaan inovatif. Taman Bacaan Inovatif yang akan dibentuk adalah sebuah wadaha/ tempat dimana tersedia buku-buku yang ditujukan untuk anak dan para orang tua murid dan wadah/tempat yang dijadikan tempat berkreatifitas untuk anak yaitu dengan melukis, meggambar, bermain puzzle dan kreatifitas tangan dari kertas origama untuk anak dan untuk orang tua murid yang menunggu anaknya di sekolah tempat ini bias dijadikan sumber ilmu untuk membaca buku selain menambah wawasan buku yang disediakan juga buku yang berisi buku kesehatan ibu dan anak, buku agama, buku parenting, buku tata boga, buku tata busana, cara bercocok tanam, dan cara membuat kerajinan tangan yang dapat dimanfaatkan secara ekonomi untuk meningkatkan ekonomi keluargatapi tetap menjalankan fungsinya sebagai ibu rumah tangga yang dapat mengurus keluarga dengan baik tanpa harus meinggalkan rumah. Buku yang disediakan untuk anak seperti buku bergambar seperti buku dongeng, buku lancar membaca, buku aksara arab, buku agama seperti buku cerita nabi dan buku sejarah, buku berhitung dan tempat menuangkan kreatifitas anak dan juga menyediakan sarana menggambar, melukis, menyusun puzzle dan membuat aneka kreatifitas dari kertas origami. Taman bacaan ini juga dimanfaatkan untuk tempat sharig informasi kesehatan keluarga tentang kesehatan dengan melakukan penyuluhan kesehatan tumbuh kembang anak sesuai tahap perkembangan usianya.

Melalui pembudayaan baca, anak akan meningkat pengetahuannya, meningkat kesehatannya, sehingga diharapkan tercapainya tumbuh kembang anak yang optimal (Berns, Roberta M, 2007). Dengan membaca pula seseorang akan terbentuk kepribadiannya menjadi lebih baik. Kepribadian adalah pola menyeluruh semua kemampuan, perbuatan serta kebiasaan seseorang, baik yang jasmani, mental, rohani, emosional maupun sosial (Mcleod, 2009). Semua ini telah tersusun dalam caranya yang khas, di bawah beraneka pengaruh dari luar. Dengan membaca buku seseorang akan memiliki ilmu dan pengetahuan yang luas, dari situ ia dapat membedakan mana yang baik dan mana yang buruk sehingga akan terbentuk pribadi 
Nurbaiti. et al. Taman Bacaan Inovatif Dalam Upaya Peningkatan...

yang jauh lebih baik dari sebelumnya (Sujiono, et all., 2007).

\section{METODOLOGI}

Metode Pengabdian ini adalah dengan mendirikan fasilitastaman bacaan inovatif dan penyuluhan kesehatan serta demonstrasi tentang cara mengidentifikasi tumbuh kembang anak yang optimal. Khalayak sasaran dalam Pengabdian Kepada Masyarakat ini adalah anak-anak, orang tua murid dan guru TK Diva Islamic School dan TK darul Madina. Diharapkan dari mereka yang telah mendapatkan layanan wadah/tempat dan informasi, sosialisasi dan pelatihan dapat menerapkan konsep tersebut didalam keluarganya. Pendekatan yang dilakukan untuk mencapai tujuan kegiatan ini adalah dengan melakukan kerjasama dan negosiasi dengan Kepala Sekolah, guru, orang tua murid dan anak-anak siswa di kedua TK tersebut.

\section{HASIL PENGABDIAN}

Setelah dipeoleh kesepakatan dengan kedua mitra mak kegiatan pengabdian masyarakat mulai dilaksanakan sesuai dengan rencana pada minggu keempat tepatnya tanggal 29 Juli 2017 di TK Diva Islamic School dengan jumlah peserta orang tua murid 35 orang dan siswa TK nya sebanyak 30 orang kegiatan diawali dengan pembukaan oleh Ketua Peneliti Nurbaiti, Ns.,S.Kep.,M.Biomed kemudian dilanjutkan dengan kata sambutan dari ketua yayasan Diva Islamic School kemudian, dilanjutkan dengan Edukasi pada orangtua dan screening tumbuh kembang anak, kemudian dilanjutkan dengan screening hipertensi dan Diabetes melitus melalui pemeriksaan tekanan darah dan Pemeriksaan Gula Darah. Pelatihan screening gangguan tumbuh kembang anak oleh tim dan mahasiswa.dan untuk anakanak TK tersebut dilakukan stimulasi tumbuh kembang anak dengan mengajarkan cara membuat kreatifitas dari origami, mengajarkan mewarnai dan menyusun puzle. Jenis kegiatan screening tumbuh kembang yang dilakukan pada anak meliputi:Deteksi dini penyimpangan pertumbuhan dengan cara mengukur Berat Badan (BB), Tinggi Badan (TB) dan Lingkar Kepala (LK). Hasilnya beberapa anak lebih kurang 20\% yang berat badannya tidak sesuai berat badan ideal.Deteksi dini penyimpangan perkembangan yaitu meliputi : Pendeteksian menggunakan Kuesioner Pra Skrining Perkembangan (KPSP), Tes Daya Lihat (TDL), Tes Daya Dengar (TDD).Hasilnya semua anak $100 \%$ normal tidak mengalami gangguan penyimpangan perkembangan.Deteksi dini penyimpangan mental emosional yaitu menggunakan : - Kuesioner Masalah Mental Emosional (KMME). Check List for Autism in Toddlers (CHAT) atau Cek lis Deteksi Dini Autis Gangguan Pemusatan Perhatian dan Hiperaktivitas (GPPH) Hasilnya tidak ada anak yang mengalami gangguan penyimpangan mental emosional $(100 \%$ normal).

Selesai dilakukan screening tumbuh kembang anak maka satu tim pengabdian masyarakat dengan didampingi ole 2 orang mahasiswa mengajarkan org tua dan guru cara menilai tumbuh kembang anak dan cara Deteksi dini penyimpangan pertumbuhan dengan cara mengukur Berat Badan (BB), Tinggi Badan (TB) dan Lingkar Kepala (LK) hasilnya 100\% peserta mampu melakukan deteksi ini. Deteksi dini penyimpangan perkembangan dan Deteksi dini penyimpangan mental emosional akan dilakukan pelatihan hanya untuk guru yang dilatih orgtua hanya diberi edukasi hasilnya sehingga para guru mampu melakukan deteksi dini terhadap penyimpangan perkembangan dan penyimpangan mental emosional pada anak. Dan orang rua tau tujuan dan 
Nurbaiti. et al. Taman Bacaan Inovatif Dalam Upaya Peningkatan...

manfaatnya. Sedangkan 1orang tim yang lain dengan didampingi 3 orang mahasiswa melakukan stimulasi tumbuh kembang anak dengan melakukan lomba mewarnai dan membuat keterampilan dari kertas origami.

\begin{abstract}
Kemudian kegiatan dilanjutkan denganScreening hipertensi dan Diabetes melitus melalui pemeriksaan tekanan darah dan Pemeriksaan Gula Darah hasilnya $25,8 \%$ terdeteksi hipertensi dan $14,3 \%$ terdeteksi diabetes melitus. Dan dilanjutkan dengan penyuluhan tentang hipetensi dan diabetes melitus dalam kegiatan ini orang tua tanpa antusia mengikuti kegiatan dan banyak bertanya. Dari seluruh yang hadir $\pm 80 \%$ bertanya tentang berbagai hal terkait tentang hipertensi dan diabetes melitus, beberapa pertanyaan yang mereka tanyakan adalah bagaimana cara mengatasi hipertensi dan diabetes melitu, apa makanan yang boleh dimakan mana yang tidak boleh dimakan, apakah kedua penyakit ini merupakan penyakit keturunan apaka bisa disembuhkan dan sebagainya, dan setelah diberi penjelasan mereka tanpa puas. Saat kegiatan penyuluhan tim juga membagikan leafleat yang dapat dibawa pulang.
\end{abstract}

\section{UCAPAN TERIMA KASIH}

Terima kasih Kepada Rektor Universitas Sumatera Utara dan Lembaga Pengabdian Pada Masyarakat Universitas Sumatera Utara Yang Telah Menfasilitasi Pelaksanaan Pengabdian Masyarakat IbM Mono Tahun ini dengan No Kontrak 3221/UN5.2.3.2.1/PPM/2017 pelaksanaan tahun 2017

\section{DAFTAR PUSTAKA}

Aisyah, S (2008). Perkembangan dan Konsep dasar Perkembangan Anak usia Dini. Jakarta.Universitas Terbuka.

Ali, N.,dan Yeni, R., (2005). Metode Pengembangan Sosial Emosional. Jakarta: Penerbit UniversitasTerbuka.

McLeod, S. A. (2009). Jean Piaget Cognitive Theory. Retrieved from http://www.simplypsychology.org/piage t.html

Briawan D, Herawati T. (2008). " Peran Stimulasi Orang tua Terhadap Perkembangan Anak

Balita Keluarga Miskin” .Jurnal Ilmu Keluarga dan Konsumen Vol 1 No 1. Januari,

2008.

Berns, Roberta M. (2007). Child, Family, School, Community. 6 th ed. USA: Wadsworth.

Suryadi, A., 2007. "Kebijakan Direktorat Pendidikan Anak Usia Dini (PAUD)" Makalah

disampaikan dalam Diskusi tentang

"Problem Pendidikan Nasional" di UMP

Sujiono, Yuliani Nuraini,dkk. 2007.

Metode Pengembangan Kognitif.

Jakarta: Universitas Terbuka. 